ROCZNIKI PEDAGOGICZNE

Tom 12(48), numer $3-2020$

DOI: https://doi.org/10.18290/rped20123-5

MARTYNA KOTYŚKO

\title{
MŁODZIEŻ I GRY KOMPUTEROWE - MOTYWY, EMOCJE I PROBLEMY ZWIĄZANE Z GRANIEM*
}

\begin{abstract}
WSTĘP
Korzystanie z Internetu dla współczesnej młodzieży stało się integralnym aspektem jej funkcjonowania. Jest to pierwsze pokolenie, które dorasta w epoce cyfrowej. Dzięki niemal stałemu dostępowi do Internetu aktywność młodych ludzi wiąże się z uczestnictwem w forach dyskusyjnych, portalach społecznościowych oraz użytkowaniem gier online. Wysoki stopień zaangażowania dzieci i młodzieży w tego rodzaju aktywności skłania naukowców do poszukiwania odpowiedzi na pytanie, w jaki sposób korzystanie $\mathrm{z}$ internetu wpływa na rozwój dziecka, a także - kiedy może prowadzić do uzależnienia (Blinka i in., 2015). Coraz więcej mówi się o potencjalnie uzależniających właściwościach gier internetowych (por. Bednarek, Andrzejewska, 2009). Problem ten jest na tyle istotny, że pojęcie ,zaburzenie korzystania z gier internetowych" - ZKGI (ang. Internet Gaming Disorder, IGD) zostało wprowadzone do Sekcji III najnowszej wersji klasyfikacji DSM-5 (American Psychiatric Association, 2013) oraz zostało uwzględnione w klasyfikacji ICD-11 (World Health Organization, 2019) w postaci dwóch jednostek: Gaming disorder oraz Hazardous gaming.

ZKGI analizuje się poprzez pryzmat dziewięciu kryteriów uwzględnionych w DSM-5, a brzmią one następująco (American Psychiatric Association, 2013):

Dr MARTYNA KotyŚKo - adiunkt, Katedra Psychologii Klinicznej, Rozwoju i Edukacji, Instytut Nauk Pedagogicznych, Wydział Nauk Społecznych, Uniwersytet Warmińsko-Mazurski w Olsztynie; adres do korespondencji: ul. Michała Oczapowskiego 2, 10-719 Olsztyn; e-mail: martyna.kotysko@uwm.edu.pl; ORCID: https://orcid.org/0000-0001-6771-5121.

* Autorka artykułu serdecznie dziękuje współpracownikom: dr. Maciejowi Michalakowi, prof. Pawłowi Izdebskiemu, mgr Karolinie Stence i dr. Jarosławowi Ocalewskiemu, z którymi prowadziła badania w ramach projektu badawczego.
\end{abstract}


I) zaabsorbowanie graniem, II) symptomy odstawienia pojawiające się po zaprzestaniu grania, III) wzrost tolerancji czasu poświęcanego na granie, IV) nieudane próby kontrolowania grania, V) utrata zainteresowania innymi hobby, VI) kontynuowanie grania pomimo świadomości szkód, jakie wyrządza, VII) oszukiwanie rodziny/terapeutów na temat czasu spędzanego na graniu w gry, VIII) ucieczka od rzeczywistości w celu uzyskania poprawy nastroju, IX) narażenie $\mathrm{z}$ powodu grania istotnych relacji interpersonalnych, edukacji, pracy czy kariery.

Według DSM-5 (American Psychiatric Association, 2013), żeby mówić o ewentualnym zaburzeniu, niezbędne jest odnotowanie wystąpienia co najmniej pięciu $\mathrm{z}$ powyższych kryteriów na przestrzeni 12 miesięcy poprzedzających badanie. Warto dodać, że wskazane kryteria diagnostyczne nie uwzględniają wieku osób badanych, tzn. kryteria opracowane dla osób dorosłych służą również do oceny zjawiska wśród dzieci i młodzieży.

Badania nad potencjalnie uzależniającymi właściwościami gier komputerowych rozpoczęły się na świecie na początku lat 80 . ubiegłego wieku. Wówczas zanotowano pierwsze przypadki nastolatków, którzy nie mogli oderwać się od gier komputerowych (Kuss, 2013). Obecnie gry, w tym komputerowe, stały się nieodłączną częścią życia młodzieży. Szacuje się, że 25\% graczy w gry komputerowe i gry wideo ma mniej niż 18 lat (Kuss i Griffiths, 2012). Z badań na populacji polskiej, prowadzonych wśród gimnazjalistów, wynika że ponad $18 \%$ nastolatków deklarowało, że gra niemal codziennie w gry typu MMORPG (ang. Massively Multiplayer Online Role Playing Game) oraz FPS (ang. First Person Shooter) (Wójcik, 2013). Badania Festl, Scharkow i Quandt (2013) dostarczają wyników, które pokazują, że młodzież w przedziale wiekowym 14-18 lat jest szczególnie narażona na wystąpienie zaburzenia korzystania $\mathrm{z}$ gier internetowych. Europejskie badania EU NET ADB, w których uwzględniona była również polska populacja młodzieży (ok. 2000 uczniów w wieku 14-17 lat), pokazały, że w naszym kraju osoby, które wykazują symptomy nadmiernego korzystania z gier, to $7,7 \%$ społeczeństwa (w grupie graczy osoby te stanowią $12,43 \%$ ). Pomiar w tym badaniu dokonywany był za pomocą polskiej wersji zagranicznego narzędzia AICA-S (the Assessment of Internet and Computer game Addiction - służy ono ocenie nałogu korzystania z Internetu i gier komputerowych) (Wójcik, 2013; Makaruk, Włodarczyk, Wójcik, 2013).

W prowadzonych dotychczas badaniach próbowano określić, jakie czynniki psychospołeczne odgrywają istotną rolę w powstawaniu ZKGI, czy też problemowego korzystania z gier. Festl i współpracownicy (2013) odnoto- 
wali, że problemowe korzystanie $\mathrm{z}$ gier związane jest $\mathrm{z}$ niskim poziomem towarzyskości, niższym poziomem postrzeganego wsparcia społecznego, niższym poczuciem własnej skuteczności, zachowaniami agresywnymi oraz niższym zadowoleniem z życia. Ponadto wspomniani badacze zwrócili uwagę, że wysoki stopień zaangażowania $\mathrm{w}$ gry może wiązać się z ich specyfiką. W badaniach Lemmensa, Valkenburg i Gentile (2015) rozpoznano dodatnie korelacje wyników otrzymanych w pomiarze ZKGI, uzyskiwanych za pomocą różnych narzędzi, z czasem grania, samotnością, agresją oraz ujemne korelacje z samooceną, prospołecznymi zachowaniami i zadowoleniem z życia. Informacje pochodzące z pracy Müller i współpracowników (2015) potwierdzają, że osoby, które można określić mianem uzależnionych od gier online - w porównaniu z osobami będącymi w strefie ryzyka, grającymi bezproblemowo i niegrającymi - deklarują częstsze występowanie problemów obejmujących następujące podskale narzędzia the Youth Self-Report (YSR): lękliwy-depresyjny, zamknięty w sobie-depresyjny, skargi somatyczne, problemy społeczne, problemy z myśleniem, problemy z uwagą, zachowania związane $\mathrm{z}$ łamaniem zasad oraz zachowania agresywne. Podobny trend odnotowano w polskiej części badania EU NET ADB, w której zostało również wykorzystane narzędzie YSR (Wójcik, 2013).

Interesujące badania zostały przeprowadzone w Niemczech. Ich celem była ocena, w jakim stopniu kryteria DSM-5 umożliwiają rozpoznanie i oszacowanie rozpowszechnienia ZKGI wśród niemieckiej młodzieży. Przebadano około 11 tysięcy uczestników w wieku 13-18 lat za pomocą skali Video Game Dependency Scale, która zawiera wszystkie dziewięć kryteriów IGD według DSM-5. U 1,16\% respondentów rozpoznano ZKGI, bazując właśnie na tych kryteriach. Grupę z rozpoznanym ZKGI porównano z osobami bez takiego rozpoznania pod względem: poczucia bycia uzależnionym od grania, czasu spędzanego na graniu w ciągu dnia, problemów ze snem, średniej ocen szkolnych, liczby zdarzeń, kiedy opuszczono zajęcia lekcyjne oraz wagarowania związanego z zaangażowaniem $\mathrm{w}$ gry. Uczniowie z ZKGI doświadczali częściej poczucia uzależnienia od grania, poświęcali na granie więcej czasu w ciągu dnia, pojawiały się u nich trudności i zakłócenia snu, ich oceny były niższe oraz częściej niż osoby bez ZKGI opuszczali szkołę i wagarowali przez gry (Rehbein, Kliem, Baier, Mößle i Petry, 2015). King i Delfabro (2016) zwrócili uwagę, że młodzież z ZKGI może przejawiać unikalne, nieprzystosowawcze przekonania, które stanowią podstawę trwałego i nadmiernego zaangażowania w gry internetowe. Należą do nich: a) przekonanie o grze jako rzeczywistej nagrodzie, b) nieprzystosowawcze i sztywne 
zasady dotyczące zachowań graczy, c) nadmierne poleganie na grach oraz zaspokojenie potrzeb zwiększania swojej samooceny, d) gra jako sposób zdobywania społecznej akceptacji.

Przebadano 824 osoby ze szkół średnich (402 mężczyzn i 422 kobiety) pod względem symptomatologii ZKGI i obecności myśli nieprzystosowawczych o grach. Wyniki pokazały, że młodzież z objawami ZKGI ma znacznie bardziej nieprzystosowawcze przekonanie o graniu niż młodzież bez ZKGI (King i Delfabro, 2016).

Paweł Izdebski w swojej monografii, dotyczącej Internetu i gier internetowych (2019), jeden z rozdziałów poświęca graczom i ich motywom związanym z graniem. Dokonał podziału na tzw. teorie ogólne (obejmując zarówno motywację do korzystania z Internetu, jak i gier) oraz specyficzne dotyczące wyłącznie grania. Wśród teorii ogólnych wyszczególnił (Izdebski, 2019): teorię użytkowania i gratyfikacji; teorię przepływu; teorię autodeterminacji; teorię społecznego uczenia się; teorię kapitału społecznego oraz model akceptacji technologii.

Jak zauważa Izdebski (2019, s. 59): „Większość badań i koncepcji wyjaśniających motywacje do grania $\mathrm{w}$ gry komputerowe dotyczy wyjaśniania aktywności graczy w określonych gatunkach gier". Wydaje się zatem, że gatunek gier ma ogromne znaczenie dla opisu motywacji graczy i nie pozostaje bez znaczenia w kontekście badań prowadzonych wśród osób grających w gry. Ważne badania w formule jakościowej, a nie ilościowej, co ma zazwyczaj miejsce w odniesieniu do badań nad graniem i graczami, przeprowadzili van Rooij, Daneels, Liu, Anrijs i Looy (2017). Wraz z zespołem poddali oni analizie 30 wywiadów, które były przeprowadzane $\mathrm{z}$ dziećmi (średnia wieku 8 lat) i ich rodzicami na temat podejmowania przez dzieci aktywności związanej z grami oraz jej zaprzestania. Wspomniani autorzy zestawili ze sobą informacje uzyskane $\mathrm{z}$ wywiadów oraz proponowane 16 kategorii motywów, względem których dokonali przyporządkowania wynikającego z kodowania odpowiedzi osób badanych. $Z$ otrzymanych danych wynikało, że teorie stosowane dotychczas $\mathrm{w}$ analizach motywacji do grania wśród osób dorosłych dosyć dobrze pozwalają analizować motywy kierujące dziećmi w tym zakresie (zarówno pod względem inicjowania aktywności, jak i jej kończenia bądź porzucania). Zwrócono jednak uwagę, że taki motyw jak poczucie autonomii czy chęć finansowego zysku nie pojawiała się $\mathrm{w}$ informacjach pozyskanych z badanej próby dzieci i ich rodziców względem chęci rozpoczęcia grania, co autorzy tłumaczą niskim wiekiem uczestników badania. Warto podkreślić, że wśród wyszczególnionych przez van Rooij i współpracowników (2017) motywów, pojawiają się takie, których wcześniej nie 
brano pod uwagę, tj. wynikające $\mathrm{z}$ samej gry oraz rodziców (związane m.in. $\mathrm{z}$ ich wpływem, postawą oraz kontrolą).

Uwzględniając powyższe informacje związane z ZKGI, jego predyktorami oraz motywami dotyczącymi grania w gry, zaprojektowane zostało badanie, którego celem było: poznanie przekonań młodzieży dotyczących gier komputerowych, ze szczególnym uwzględnieniem motywacji do grania, emocji pojawiających się w związku z nim, a także problemów, które mogą występować wskutek nadmiernego grania.

\section{METODOLOGIA BADAŃ WŁASNYCH}

\section{Cel badawczy i problemy badawcze}

Celem przeprowadzonego badania własnego było poznanie, istotnej z punktu widzenia młodzieży, sfery aktywności, jaką stanowią gry komputerowe. Pod uwagę zostały wzięte cztery aspekty: aktywność w grach i ich dostosowanie do wieku odbiorcy, motywacja do grania, emocje związane z grami oraz potencjalne zagrożenia i trudności, jakie mogą wynikać z zaangażowania w gry.

W odniesieniu do przedstawionego celu, sformułowano pięć szczegółowych problemów badawczych:

1) Jaki odsetek uczniów gra w gry, w tym gry online, i jakie urządzenia wykorzystuje do tej aktywności?

2) Czy gry, w które grają uczniowie, są dostosowane do ich wieku?

3) Jakie są główne motywy grania w gry wśród uczniów szkoły podstawowej i gimnazjum oraz co sprawia, zdaniem uczniów, że ich rówieśnicy nie grają w gry?

4) Jakie emocje towarzyszą uczniom w trakcie gry i po jej zakończeniu oraz czy występują różnice $\mathrm{w}$ identyfikowanych emocjach między dziewczętami a chłopcami?

5) W jaki sposób uczniowie postrzegają zjawisko nadmiernego grania w gry komputerowe i czy występują różnice między perspektywą młodszych i starszych uczniów?

Dzięki odpowiedziom na postawione pytania możliwe będzie lepsze zrozumienie popularności gier wśród młodzieży oraz zweryfikowanie, jaka jest jej świadomość dotycząca zagrożeń związanych z potencjalnym uzależnieniem od tej aktywności. Pozyskane informacje mogą stanowić przydatny element związany z edukacją i profilaktyką w tym zakresie. 


\section{Osoby badane}

Realizowane badanie było częścią szerszego projektu badawczego pod tytułem „Zaburzenie korzystania z gier internetowych - charakterystyka i rozpowszechnienie zjawiska oraz jego psychologiczne korelaty wśród uczniów szkoły podstawowej i gimnazjum na terenie województwa kujawsko-pomorskiego i warmińsko-mazurskiego", zadanie publiczne współfinansowane ze środków Funduszu Rozwiązywania Problemów Hazardowych będących w dyspozycji Ministra Zdrowia oraz ze środków Uniwersytetu Kazimierza Wielkiego w Bydgoszczy (umowa nr 191/HM/2017). Działania badawcze, których dotyczy niniejszy artykuł, były prowadzone od września do listopada 2017 r. na terenie dwóch województw: warmińsko-mazurskiego i kujawsko-pomorskiego. Wzięło w nich udział łącznie 316 uczniów uczęszczających do II i III klasy gimnazjum $(n=166)$ oraz do V, VI i VII klasy szkoły podstawowej $(n=150)$. W analizowanej próbie znalazło się 168 chłopców oraz 148 dziewcząt, były to zarówno osoby grające i niegrające w gry komputerowe.

\section{Metoda badawcza i narzędzie badawcze}

Wykorzystaną metodą badawczą był sondaż diagnostyczny, a zastosowaną techniką wywiad zbiorowy (standaryzowany, z użyciem kwestionariusza wywiadu własnego autorstwa zawierającego pytania o formule zamkniętej i otwartej). Kwestionariusz uwzględniał 9 pytań dotyczących kilku obszarów związanych z graniem w gry komputerowe. Pierwszy z nich odnosił się do samej aktywności w grach i wykorzystywanych do tego celu urządzeniach (pyt. 1-3). Drugi obejmował indywidualne preferencje związane $\mathrm{z}$ grami (pyt. 4). Trzecim była motywacja związana $z$ graniem i powody, dla których uczniowie grają oraz nie grają w gry (pyt. 5-6). Czwartym aspektem poruszanym w trakcie badania były emocje towarzyszące uczniom w trakcie gry i po jej zakończeniu (pyt. 7). Ostatni obszar dotyczył zjawiska nadmiernego zaangażowania w gry (pyt. 8-9). Na potrzeby badania powstał specjalny arkusz pomocniczy ułatwiający rejestrowanie odpowiedzi uczniów, który był wypełniany w trakcie każdego wywiadu przez pomocnika moderatora.

\section{Procedura badawcza}

Badanie miało formę bezpośredniej rozmowy z uczniami na temat gier komputerowych (pod tym hasłem należy rozumieć wszystkie gry, w które można grać nie tylko na komputerze, ale również na telefonie, tablecie czy konsoli). W każdym z wywiadów uczestniczyło średnio 12 uczniów. Badanie 
było prowadzone przez dwóch badaczy - moderatora wywiadu i pomocnika, który notował informacje od osób badanych i prowadził obserwację. Czas trwania wywiadu wynosił ok. 45 minut - jedną jednostkę lekcyjną. Każde spotkanie odbywało się według ustalonego schematu, który uwzględniał sekwencję zadawanych uczniom pytań oraz towarzyszącą im formę aktywności (m.in. odpowiedź indywidualną, podniesienie ręki, zapisanie odpowiedzi na kartce samoprzylepnej i przyczepienie jej na grupowym brystolu, wpisanie odpowiedzi na rysunku). Zdecydowano się na urozmaicenie wywiadów poprzez przedstawione powyżej aktywności, aby utrzymać motywację uczniów do udziału w badaniu oraz sprawić, by stało się ono dla nich bardziej atrakcyjne. Zgromadzone w badaniu dane poddano analizie ilościowej, jak i jakościowej.

\section{WYNIKI}

Uczniów zapytano, czy grają w gry (zarówno offline, jak i online) oraz $\mathrm{z}$ jakich urządzeń w tym celu korzystają. Uzyskane dane pozwoliły na udzielenie odpowiedzi na problem badawczy numer 1. Zdecydowana większość uczestników badania zadeklarowała, że gra w gry komputerowe - ok. 81\%. Należy jednak podkreślić, że uczniowie nie określali, jak często i z jaką intensywnością grają, zatem wymieniona wartość procentowa wskazuje wyłącznie, czy taka aktywność jest przez nich podejmowana. Spośród 316 uczniów aż 209 zadeklarowało granie w gry internetowe (stanowi to $66 \%$ analizowanej próby). W Tabeli 1 znajdują się dane ukazujące wskazania uczniów związane z urządzeniami, jakie wykorzystują do tego, by grać w gry.

Tabela 1. Urządzenia wykorzystywane przez młodzież do grania w gry

\begin{tabular}{|l|c|c|c|}
\hline Urządzenie & Szkoła podstawowa $n=166$ & Gimnazjum $n=150$ & Ogółem $N=316$ \\
\hline Komputer & $76 \%$ & $74 \%$ & $75 \%$ \\
\hline Konsola & $51 \%$ & $45 \%$ & $48 \%$ \\
\hline Tablet & $38 \%$ & $14 \%$ & $27 \%$ \\
\hline Smartfon & $86 \%$ & $56 \%$ & $72 \%$ \\
\hline
\end{tabular}

Źródło: badania własne. Procenty nie sumują się do 100, ponieważ uczestnicy mogli wskazać kilka urządzeń 
Wśród uczniów szkoły podstawowej to smartfon jest urządzeniem, które było wymieniane najczęściej jako wykorzystywane do grania w gry, a wśród gimnazjalistów dominował komputer. Obie grupy w najmniejszym stopniu korzystają do grania $\mathrm{z}$ tabletów.

W nawiązaniu do drugiego problemu badawczego poproszono uczniów, aby wskazali maksymalnie trzy gry, w które lubią grać. Uczniowie podali łącznie aż 161 tytułów różnych gier. Wśród dziewięciu najpopularniejszych, dwie są przeznaczone dla osób powyżej 18 roku życia według Ogólnoeuropejskiego Systemu Klasyfikacji Gier (PEGI) (https://pegi.info/pl). Była to gra internetowa Counter-Strike - Global Offensive - zwana popularnie CS'em oraz gra Grand Theft Auto - w skrócie GTA.

Marcin Strzyżewski (2017, akapit 2), na stronie internetowej znanego magazynu Komputer Świat, w następujący sposób opisuje podstawy gry Counter-Strike: „Dwie drużyny: terroryści i antyterroryści strzelają do siebie nawzajem, próbując jednocześnie wypełnić określone cele, takie jak uwolnienie zakładników, czy podłożenie bomby w odpowiednim miejscu". Dodatkowo na portalu GRY-Online możemy przeczytać, że „Za każdego wyeliminowanego przeciwnika nagradzani jesteśmy gotówką, za którą na początku kolejnej rundy możemy kupić lepszą broń i uzbrojenie" (Counter-Strike: Global Offensive PC, b.d., akapit 3 ). Jednym z celów gry jest więc zabicie jak największej liczby przeciwników.

Informacje na temat gry GTA V na stronie internetowej Komputer Świat są następujące: „Gra opowiada o przygodach trzech bandziorów, których ścieżki niekiedy się przecinają, przez większość czasu jednak biegną osobno. Grać możemy każdym z nich, przełączając się na wybraną postać w dowolnym momencie oprócz misji, które przypisane są do konkretnych postaci" (Poznaj świat Grand Theft Auto V, 2013, sekcja „Kariera gangstera”). Gra odznacza się dużą brutalnością oraz wulgarnością w stosowanym języku, zawiera także wątki o charakterze seksualnym, a co najważniejsze - wykreowany świat i zadania do realizacji z pewnością nie są przeznaczone dla nieletniego odbiorcy. Potwierdzeniem tego jest opis na wspomnianej wcześniej stronie internetowej: „Wymuszamy zatem haracze, używamy rottweilera do polowania na ludzi, brutalnie bijemy słabszych, w pewnym momencie nawet torturujemy jeńca, wyrywając mu zęby kombinerkami. I nie ma tu puszczania oka, nie ma wytłumaczenia, że robimy tak dla wyższych celów i dobra ludzkości, nie - po prostu taki jest bandycki fach. Niektóre sceny są w stanie wstrząsnąc nawet całkiem dorosłym graczem" (Poznaj świat Grand Theft Auto V, 2013, sekcja „Poważna sprawa”). 
Na podstawie powyższych opisów gier można łatwo zauważyć, że nie są one przeznaczone dla uczniów szkół podstawowych, ani uczniów gimnazjum. $\mathrm{Z}$ pewnością tym, co zachęca uczniów do grania w grę Counter Strike, jest fakt, że rywalizacja w zakresie tej gry stanowi odmianę tzw. e-sportu, gdzie drużyny z różnych stron świata mogą ze sobą konkurować, brać udział w zawodach, a prowadzone rozgrywki można oglądać m.in. w telewizji czy Internecie, podobnie jak występy tradycyjnych sportowców. Niektórym z uczniów marzy się zostanie profesjonalnym graczem (podczas rozmów z uczniami padały takie odpowiedzi), by w przyszłości móc zarabiać na tym pieniądze.

Analizie poddano powody wskazywane przez uczniów jako te, które sprawiają, że grają w gry (odniesienie do problemu badawczego numer 3). Na podstawie odpowiedzi udzielanych przez osoby badane wyodrębniono 29 motywów. Zostały one zebrane $\mathrm{w}$ Tabeli 2 razem $\mathrm{z}$ wartościami procentowymi, które wyrażają popularność motywu wśród uczniów.

Tabela 2. Motywy, dla których uczniowie grają w gry komputerowe

\begin{tabular}{|l|l|l|l|}
\hline Nazwa motywu & $\mathbf{\%}$ & Nazwa motywu & $\%$ \\
\hline Rozrywka/Przyjemność & 74 & Uzależnienie/Przymus & 3 \\
\hline Nuda & 58 & Granie ze znajomymi & 3 \\
\hline Nauka/Umiejętności/Kompetencje & 31 & Dla fabuły & 3 \\
\hline Odpoczynek psychiczny/Odstresowanie się & 23 & Dla aktywności fizycznej & 3 \\
\hline Kontakt z innymi/Relacje & 22 & Brak innych opcji/możliwości & 3 \\
\hline Dla zabicia czasu & 17 & Lenistwo & 3 \\
\hline Ciekawość & 15 & By zostać e-sportowcem & 2 \\
\hline Rywalizacja & 15 & Pieniądze & 2 \\
\hline Dla wyżycia się & 9 & Odskocznia od codzienności & 2 \\
\hline Rozwój wyobraźni & 8 & „Bo to wciąga” & 2 \\
\hline Hobby & 7 & Namowa innych & 2 \\
\hline Brak innych obowiązków/jest czas & 7 & Osiąganie celów & 1 \\
\hline Odcięcie od świata zewnętrznego & 5 & Brak innych zainteresowań & 1 \\
\hline Moda & 4 & Eksploracja świata gry & 1 \\
\hline By nie odrabiać lekcji & 4 & &
\end{tabular}

Źródło: badania własne. Procenty nie sumują się do 100, ponieważ uczestnicy mogli wskazać kilka motywów 
$\mathrm{Na}$ podstawie danych z Tabeli 2 można stwierdzić, że głównym motywem, dla którego uczniowie grają w gry, jest zabawa i rozrywka. Co istotne, uczniowie twierdzą, że grają z nudów - co dla osób dorosłych, jest przesłanką, by podejmować działania mające na celu pomoc dzieciom w organizacji czasu. Interesującym motywem podawanym przez uczniów był rozwój umiejętności/kompetencji oraz możliwość uczenia się. W rozmowach uczniowie wskazywali, że uczą się dzięki graniu z innymi graczami współpracy, języków obcych oraz pozyskują informacje na tematy, które ich interesują. Gry również stanowią dla dzieci sposób na odstresowanie się i formę psychicznego odpoczynku.

Uczniowie pytani o powody, dla których inne osoby w ich wieku nie grają w gry, najczęściej wskazywali następujące przyczyny (podano je roboczo kategoryzacji i przedstawiono w nawiasach): brak sprzętu/dostępu do Internetu (bariera techniczna), brak zainteresowania taką aktywnością/niechęć do spędzania czasu w taki sposób, traktowanie grania jako stratę czasu i chęć spędzania go na nauce (czynniki wewnętrzne leżące po stronie osoby niegrającej), brak czasu, zakaz ze strony rodziców, brak odpowiednich środków finansowych, by grać (czynniki zewnętrzne utrudniające podjęcie badanej aktywności), oraz, co interesujące, uczniowie twierdzą, że ktoś nie gra w gry ponieważ nie potrafi (brak odpowiednich umiejętności). Przedstawione informacje warto uzupełnić o wnioski płynące z bezpośrednich komentarzy uczniów, dla których niepodejmowanie aktywności związanej z grami jest trudne do zrozumienia, szczególnie, że większość ich rówieśników gra.

W celu uzyskania odpowiedzi na pytanie dotyczące emocji towarzyszących uczniom w trakcie gry i po jej zakończeniu (problem badawczy numer 4), posłużono się grafiką zawierającą osiem dziecięcych twarzy z podpisem określającym wyrażaną emocję. Każdy grający w gry uczestnik miał za zadanie zaznaczyć emocje, które czuje w trakcie gry oraz po jej zakończeniu. Przeanalizowano oddzielnie emocje towarzyszące chłopcom i dziewczynkom. Dane na ten temat zostały zawarte w Tabeli 3.

Zarówno w grupie chłopców, jak i wśród dziewcząt dominującą emocją podczas grania i po jego zakończeniu była wesołość i szczęście. Wyniki przeprowadzonego testu $\chi^{2}$ wykazały, że nie ma między grupami różnic w zakresie identyfikacji tych emocji w trakcie i po grze. Uzyskany rezultat może stanowić potwierdzenie dla powszechnego przekonania, że gry stanowią dla dzieci głównie źródło pozytywnych emocji. Drugą emocją najczęściej wskazywaną przez chłopców była złość, która wśród dziewcząt wystąpiła na trzecim miejscu (w tym przypadku również wykonano analizę 
testem $\chi^{2}$ i nie odnotowano różnic między grupami dotyczącymi występowania tej emocji w trakcie rozgrywki i po jej zakończeniu). Najrzadziej uczniowie deklarowali odczuwanie wstydu. W obu grupach (dziewcząt i chłopców) widoczny był wzrost intensywności związany z pojawieniem się emocji smutku i stanu zmęczenia po grze.

Tabela 3. Emocje towarzyszące uczniom w trakcie gry i po jej zakończeniu

\begin{tabular}{|l|l|l|l|l|l|l|l|l|}
\hline \multirow{2}{*}{ Emocje } & \multicolumn{3}{|l}{ Chłopcy, n=168 } & \multicolumn{3}{l|}{ Dziewczęta, n=148 } \\
\cline { 2 - 9 } & W tracie gry & \multicolumn{2}{l}{ Po grze } & \multicolumn{2}{l|}{ W tracie gry } & \multicolumn{2}{l|}{ Po grze } \\
\cline { 2 - 9 } & $n$ & $\%$ & $n$ & $\%$ & $n$ & $\%$ & $n$ & $\%$ \\
\hline Szczęście & 124 & 73,8 & 74 & 44 & 105 & 71 & 67 & 45,3 \\
\hline Strach & 17 & 10,1 & 10 & 5,9 & 28 & 18,9 & 9 & 6,1 \\
\hline Smutek & 17 & 10,1 & 49 & 29,2 & 21 & 14,2 & 25 & 16,9 \\
\hline Złość & 126 & 75 & 72 & 42,9 & 86 & 58,1 & 42 & 28,4 \\
\hline Wstyd & 7 & 4,2 & 5 & 3 & 2 & 1,4 & 4 & 2,7 \\
\hline Zmęczenie & 14 & 8,3 & 62 & 36,9 & 36 & 24,3 & 41 & 27,7 \\
\hline Wesołość & 141 & 83,9 & 79 & 47 & 108 & 73 & 56 & 37,8 \\
\hline Zaskoczenie & 99 & 58,9 & 35 & 20,8 & 65 & 43,9 & 30 & 20,3 \\
\hline
\end{tabular}

Źródło: badania własne. Procenty nie sumują się do 100, ponieważ uczestnicy mogli wskazać kilka emocji

Ostatni problem badawczy analizowany $w$ ramach badania dotyczył zagadnienia nadmiernego grania w gry. Zapytano uczniów, „Czy w gry można grać za dużo?". Na tak sformułowane pytanie 23\% uczniów szkoły podstawowej $(n=38)$ i 9\% uczniów gimnazjum $(n=14)$ odpowiedziało, że „Nie można grać za dużo". Wynik porównania testem $\chi^{2}$ był istotny statystycznie, co świadczy o różnicy w odpowiedziach młodszych i starszych uczniów. Być może młodsi uczniowie mają inną percepcję czasu przeznaczanego na granie, oraz związanych z tym konsekwencji, w porównaniu z uczniami gimnazjum, których świadomość w tym zakresie wydaje się większa. Należy również powiedzieć, że sam czas przeznaczany przez dziecko na gry nie stanowi wyznacznika tego, że ma ono problem z graniem. Istnieje cienka granica między problemowym graniem a pasją do grania, która przekłada się na zaangażowanie znacznej ilości czasu na tą aktywność. Kontynuacją poruszonego aspektu problemów związanych z graniem była prośba do uczniów o wskazanie, jak ich zdaniem zachowuje się osoba, która gra za dużo, oraz by określili, jakie mogą się jej przytrafić negatywne konsekwencje w obliczu 
takiego postępowania. Zestawienie najpopularniejszych odpowiedzi uczniów szkoły podstawowej i gimnazjum znajduje się w Tabeli 4.

Tabela 4. Zestawienie najczęstszych odpowiedzi uczniów na temat objawów zaburzenia korzystania z gier i negatywnych konsekwencji z tym związanych (odpowiedzi zostały skategoryzowane)

\begin{tabular}{|l|l|}
\hline Odpowiedzi - szkoła podstawowa & Odpowiedzi - gimnazjum \\
\hline Agresja & $\begin{array}{l}\text { Problem z odróżnieniem świata wirtualnego } \\
\text { od rzeczywistego }\end{array}$ \\
\hline Zmęczenie/Senność/Osłabienie & Agresja \\
\hline Gorszy wzrok & Gorszy wzrok \\
\hline $\begin{array}{l}\text { Gorsze wyniki w nauce/ } \\
\text { Zaniedbanie obowiązków szkolnych }\end{array}$ & Pobudzenie/Stres \\
\hline Pobudzenie/Stres & Zmęczenie/Senność/Osłabienie \\
\hline Otyłość & $\begin{array}{l}\text { Gorsze wyniki w nauce/ } \\
\text { Zaniedbanie obowiązków szkolnych }\end{array}$ \\
\hline $\begin{array}{l}\text { Utrata relacji ze znajomymi/ } \\
\text { Zaniedbanie tych relacji }\end{array}$ & Depresja/Smutek \\
\hline Problemy z koncentracją & $\begin{array}{l}\text { Możliwość wyrządzenia sobie krzywdy/samo- } \\
\text { bójstwo/śmierć }\end{array}$ \\
\hline $\begin{array}{l}\text { Problem z odróżnieniem świata wirtualnego } \\
\text { od rzeczywistego }\end{array}$ & Mówienie wyłącznie o graniu \\
\hline „Uzależnienie” & Wady kręgosłupa \\
\hline
\end{tabular}

Źródło: badania własne. Odpowiedzi zostały uszeregowane w kolumnach pod względem popularności

Uczestnicy spotkań bardzo dobrze poradzili sobie z zadaniem wskazania objawów towarzyszących osobie, która nadmiernie gra w gry. Uczniowie szkoły podstawowej najczęściej zwracali uwagę na agresję w zachowaniu, zmęczenie oraz problemy ze wzrokiem osoby, która „gra za dużo”. Uczniowie gimnazjum natomiast na pierwszym miejscu wskazywali, że taka osoba ma problemy z odróżnieniem świata wirtualnego od rzeczywistego. Dodatkowo wspominali o możliwości pogorszenia się nastroju, a nawet wyrządzenia sobie krzywdy przez taką osobę. Dane zawarte w Tabeli 4 zawierają odpowiedzi, które pojawiały się najczęściej w rozmowach $\mathrm{z}$ uczniami, ale należy również podkreślić, że podawali oni inne wyznaczniki problemowego grania, a były to takie stwierdzenia, jak m.in.: nieustanna myśl o graniu, wulgarność w języku i jego zubożenie, niższa samoocena, niedowaga (spowodowana zaniedbaniem własnych potrzeb jedzeniowych), pogorszenie zdrowia 
fizycznego (mniejsza odporność) i psychicznego, wydawanie wszystkich pieniędzy na gry, czy też to, że taka osoba głównie koncentruje całą swoją aktywność, myśli oraz emocje na graniu. Co więcej - uczniowie poruszyli $\mathrm{w}$ rozmowach niezwykle istotną kwestię, jaką jest wystąpienie zmiany w osobie dotkniętej problemem nadmiernego korzystania z gier. Ich spostrzegawczość pokazuje, że rówieśnicy osoby z problemem mogą być cennym źródłem informacji, ponieważ są w stanie zauważyć dokonującą się w niej zmianę, która być może nam - dorosłym - gdzieś umyka.

\section{DYSKUSJA I WNIOSKI}

Przedstawione wyniki, uzyskane w ramach badania własnego, ukazują spojrzenie młodzieży na zjawisko korzystania z gier komputerowych. Gry z pewnością stanowią dla niej istotną część funkcjonowania (zdecydowana większość uczniów gra - jest to ponad $80 \%$ uczestników badania) i przestrzeni do realizacji różnych potrzeb. Jak twierdzi Magdalena Rowicka $(2018$, s. 43$)$ : ,[...] granie w gry komputerowe to przede wszystkim jedna z form rozrywki. Jest ona prawdopodobnie dlatego tak atrakcyjna dla młodych osób, że dostarcza bardzo dużo różnorodnej stymulacji. W zależności od tego, jakie mamy preferencje, motywacje czy potrzeby, to znajdziemy taką grę, która na nie odpowiada i je spełnia”. Powyższe słowa znajdują odbicie w rezultatach przeprowadzonego badania. Dla zdecydowanej większości osób badanych gry w głównej mierze są rozrywką i sposobem na nudę. Stanowią również przestrzeń do nabywania bądź rozwoju posiadanych kompetencji. Uczniowie wskazywali na możliwość odstresowania się dzięki graniu, podkreślali również aspekt społeczny gier, który dotyczył kontaktu $\mathrm{z}$ innymi osobami lub wchodzenia $\mathrm{z}$ nimi w relacje. Motywy, wskazywane przez uczniów jako te, którymi kierują się, podejmując aktywność związaną z grami, również można ująć w kategorie wyszczególnione w badaniach van Rooij i współpracowników (2017), np. osiągnięć, przyjemności, rywalizacji, motywu społecznego, samoregulacji czy grania traktowanego jako nawyk.

W prezentowanym badaniu analizowano również emocje, jakie towarzyszą nastolatkom zarówno podczas grania, jak i po jego zakończeniu. Zasadniczo gry sprawiają, że młodzież odczuwa emocje pozytywne, m.in. szczęście i wesołość w trakcie gry i po niej, należy jednak zwrócić szczególną uwagę na fakt, że w przypadku tak chłopców, jak i dziewcząt kolejną dominującą emocją jest złość. Smutek, który w trakcie grania pojawia się rela- 
tywnie rzadko, w relacjach badanych chłopców nasilał się po zakończeniu gry. Pojawia się zatem pytanie, czy młodzież potrafi sobie poradzić z tymi emocjami i jaki ewentualnie wpływ mają one na ich funkcjonowanie? Odpowiedź na nie wymaga dalszych działań badawczych zorientowanych na wywiady indywidualne.

Uczniowie nie mieli problemu ze scharakteryzowaniem osoby, która gra w gry za dużo (to pojęcie było stosowane celowo, aby uniknąć słowa „uzależnienie", mogącego w sposób bezpośredni wpływać na odpowiedzi osób badanych). Dostrzegają oni u takiej osoby nie tylko objawy fizyczne, takie jak otyłość, pobudzenie czy senność, ale i psychiczne w postaci zaniedbania relacji z innymi, agresję czy smutek. W dyskusji na temat objawów i skutków nadmiernego grania uczniowie posługiwali się również przykładami z własnego otoczenia, które dotyczyły znanych im osób mających problem w tym zakresie. Dostrzeganie przez nich sygnałów problematycznego korzystania z gier pokazuje, że to zjawisko nie jest im obce.

Informacje pozyskane $w$ ramach przeprowadzonego badania wskazują, że uczniowie mają dostęp do gier nieodpowiednich do swojego wieku i korzystają z nich. Należy zatem podjąć działania, aby we właściwą wiedzę i prawidłowe postawy wyposażyć rodziców bądź opiekunów prawnych młodzieży zapewni to nie tylko kontrolę nad tym, w co grają dzieci, ale sprawi, że rodzice czy opiekunowie będą bardziej świadomi podejmowanych wyborów dotyczących np. zakupu gier. Jednym z działań, które dorośli, zarówno rodzice, nauczyciele, pedagodzy oraz psychologowie powinni mieć na względzie, to poznanie świata gier, w które grają dzieci. Umożliwi to znalezienie wspólnego języka, zrozumienie, co takiego mają w sobie gry, że dzieci tak je lubią i angażują w nie swój czas - bez postrzegania tego zajęcia wyłącznie w kategoriach prowadzącej donikąd rozrywki lub źródła potencjalnego uzależnienia. To ważne, ponieważ uczniowie potrafili wskazać pozytywne, w ich mniemaniu, strony gier komputerowych - zrozumienie ich perspektywy to klucz do skutecznej komunikacji, również w kontekście oddziaływań prewencyjnych. Naukowców interesuje poznanie mechanizmów prowadzących do wystąpienia u najmłodszych problemu związanego z grami, aby tę wiedzę móc później przekuć we wskazówki, które pomogą tworzyć skuteczne oddziaływania profilaktyczne oraz pomocowe. 


\section{BIBLIOGRAFIA}

American Psychiatric Association (2013). Diagnostic and statistical manual of mental disorders (5th ed.). Washington: Author.

Bednarek, J., ANDrzeJewska, A. (red.) (2009). Cyberświat - możliwości i zagrożenia. Warszawa: Wydawnictwo Akademickie Żak.

Blinka, L., ŠKaŘupovÁ, K., ŠevčíkovÁ, A., WÖlfling, K., Müller, K.W., Dreier, M. (2015). Excessive internet use in European adolescents: what determines differences in severity? International Journal Of Public Health, 60(2), 249-256.

Counter-Strike: Global Offensive PC. (b.d.). GRYOnline.Pl, https://www.gry-online.pl/gry/counterstrike-global-offensive/z02d7c\#pc (dostęp: 20.02.2018).

Festl, R., Scharkow, M., QuAndT, T. (2013). Problematic computer game use among adolescents, younger and older adults. Addiction, 108, 592-599.

IZDEBSKI, P. (2019). Internet i gry internetowe. Warszawa: Wydawnictwo Naukowe PWN.

King, D.L., DelfabBro, P.H. (2016). The Cognitive Psychopathology of Internet Gaming Disorder in Adolescence. Journal Of Abnormal Child Psychology, 44(8), 1635-1645. doi:10.1007/ s10802-016-0135-y.

Kuss, D.J. (2013). Internet gaming addiction: Current perspectives. Psychology Research and Behavior Management, 6, 125-137.

Kuss, D.J., GRIFFITHS, M.D. (2012). Online gaming addiction in children and adolescents: A review of empirical research. Journal of Behavioral Addictions, 1(1), 3-22.

Lemmens, J.S., Valkenburg, P.M., Gentile, D.A. (2015). The Internet Gaming Disorder Scale. Psychological Assessment, 27(2), 567-582.

Makaruk, K., WŁodArczyK, J., Wóscik, S. (2013). Metodologia badania EU NET ADB. Dziecko krzywdzone. Teoria, badania, praktyka, 12(1), 7-11.

Müller, K., Janikian, M., Dreier, M., Wölfling, K., Beutel, M., Tzavara, C., ... Tsitsika, A. (2015). Regular gaming behavior and internet gaming disorder in European adolescents: results from a cross-national representative survey of prevalence, predictors, and psychopathological correlates. European Child \& Adolescent Psychiatry, 24(5), 565-574.

Poznaj świat Grand Theft Auto V. Komputer Świat.https://www.komputerswiat.pl/aktualnosci/inne/ poznaj-swiat-grand-theft-auto-v/30qctp0 (dostęp: (18.09.2013).

Rehbein, F., Kliem, S., BAier, D., Mößle, T., Petry, N.M. (2015). Prevalence of internet gaming disorder in German adolescents: diagnostic contribution of the nine DSM-5 criteria in a state-wide representative sample. Addiction, 110(5), 842-851. doi:10.1111/add.12849.

Rowicka, M. (2018). E-uzależnienia. Teoria, profilaktyka, terapia. Warszawa: Krajowe Biuro do Spraw Przeciwdziałania Narkomanii oraz Fundacja Praesterno.

STRZYŻEWSKI, M. (2017). Skąd wziąt się Counter-Strike? Gobalny fenomen ma już ponad póttorej dekady. Komputer Świat, https://www.komputerswiat.pl/gamezilla/aktualnosci/skad-wzial-siecounter -strike-gobalny-fenomen-ma-juz-ponad-poltorej-dekady/82t3cn3 (dostęp: 17.02.2017).

van Rooij, T., Daneels, R., Liu, S., AnRiJs, S., Van Looy, J. (2017). Children's Motives to Start, Continue, and Stop Playing Video Games: Confronting Popular Theories with Real-World Observations. Current Addiction Reports, 4, 323-332.

World HeAlth ORGANIZATION (2019). International statistical classification of diseases and related health problems (11th ed.), https://icd.who.int/. 
WóJCIK, S. (2013). Gry online - korzystanie i nadużywanie wśród młodzieży. Wyniki badania EU NET ADB. Dziecko Krzywdzone. Teoria, Badania, Praktyka, 12(1), 24-26.

\section{MŁODZIEŻ I GRY KOMPUTEROWE - MOTYWY, EMOCJE I PROBLEMY ZWIAZZANE Z GRANIEM}

\section{STRESZCZENIE}

W niniejszym artykule poddano analizie zjawisko korzystania przez młodzież z gier komputerowych. Celem przeprowadzonego badania własnego było poznanie i analiza motywów, emocji i problemów związanych z zaangażowaniem młodzieży w gry. Wykorzystaną metodą badawczą był sondaż diagnostyczny, a zastosowaną techniką wywiad zbiorowy. W badaniach wzięło udział 316 uczniów szkół podstawowych (klasy V-VII) i gimnazjów (klasy II i III) z województwa warmińsko-mazurskiego oraz kujawsko-pomorskiego.

Wyniki badania pokazują, że uczniów motywuje do grania przede wszystkim chęć rozrywki i przyjemność grania, ale gry stanowią dla nich także sposób na przeciwdziałanie nudzie. Uczestnicy badania wskazywali również na motywy utylitarne związane z grami, takie jak: możliwość nabycia nowych kompetencji czy nauka nowych umiejętności. Młodzież, grając w gry, doświadcza głównie emocji pozytywnych, jednak znacząca liczba uczniów wskazuje, że odczuwa złość w trakcie grania oraz po jego zakończeniu. Uczestnicy potrafili scharakteryzować osobę, która ich zdaniem korzysta z gier w sposób nadmierny.

Słowa kluczowe: gry komputerowe; młodzież; zaburzenie korzystania z gier internetowych; motywacja do grania.

\section{YOUTH AND VIDEO GAMES - MOTIVES, EMOTIONS AND PROBLEMS RELATED TO GAMING}

\section{SUMMARY}

This article analyzes the phenomenon of using computer games by young people. The aim of the own study was to learn and analyze the motives, emotions and problems related to the involvement of youth in gaming. The research method used was the diagnostic survey and the technique used was collective interview. The study involved 316 students from primary school (from the fifth to seventh grade) and junior high school (second and third class) from the Warmian-Masurian and Kuyavian-Pomeranian Voivodships.

The results of the study show that students motivate to play, above all, the desire to entertain and enjoy playing, but games are also a way for them to counteract boredom. Participants also pointed out utilitarian motives related to games, such as the opportunity to acquire new competences or learn new skills. Young people experience mainly positive emotions while playing, but a significant number of students indicate that they feel anger during and after playing. The participants were able to characterize the person who, in their opinion, uses games excessively.

Key words: video games; youth; internet gaming disorder; motivation to play. 